\title{
Spatial distribution of heavy metals in surface sediments of Kalametiya Lagoon in southern Sri Lanka; insight towards pollution status and socio-economic interactions
}

\author{
Sunanda Kodikara ( $\square$ sunandaruh@gmail.com ) \\ University of Ruhuna \\ Hossein Tiemoory \\ ULB Belgium \\ Mangala Chathura De Silva \\ University of Ruhuna \\ Pathmasiri Ranasinghe \\ ITI Colombo \\ Sudarshana Somasiri \\ ITI Colombo \\ Sanduni K Madarasinghe \\ University of Ruhuna \\ Udara Gunathilake \\ University of Ruhuna

\section{Danaee} \\ University of Malaya Faculty of Medicine \\ Jayatissa LP \\ University of Ruhuna \\ Andruie Julian \\ French Institute of Pondicherry: Institut Francais de Pondichery \\ Farid DAHDOUH-GUEBAS \\ Université Libre de Bruxelles: Universite Libre de Bruxelles
}

\section{Research Article}

Keywords: Heavy metals, kernel density maps, fertilizers, pesticides, Sri Lanka

Posted Date: September 27th, 2021

DOI: https://doi.org/10.21203/rs.3.rs-936004/v1

License: (a) (i) This work is licensed under a Creative Commons Attribution 4.0 International License. Read Full License 


\section{Abstract}

Heavy metal (HM) pollution has become a serious threat to coastal aquatic ecosystems. This study, therefore, aimed at assessing the spatial distribution of selected heavy metals/metalloids including Arsenic (As), Cadmium (Cd), Chromium ( $\mathrm{Cr}$ ), Lead (Pb), and Mercury $(\mathrm{Hg})$ in surface sediment $(0-15 \mathrm{~cm})$ samples collected across Kalametiya Lagoon in southern Sri Lanka. Forty-one (41) grid points of the lagoon were sampled and the sediment samples were analyzed for HM content by using ICP-MS. A questionnaire survey was carried out to investigate the possible sources for $\mathrm{HM}$ pollution in Kalametiya Lagoon. Water $\mathrm{pH}$ and salinity showed significant variation across the lagoon. Overall mean value of $\mathrm{pH}$ and salinity were $6.68 \pm 0.17$ and $2.9 \pm 2.2 \mathrm{PSU}$ respectively. The spatial distribution of the heavy metals was not monotonic and showed a highly spatial variation. The kernel density maps of the measured heavy metals demarcated several different areas of the lagoon. The mean contents of $\mathrm{As}, \mathrm{Cd}, \mathrm{Cr}, \mathrm{Hg}$, and $\mathrm{Pb}$ were lower than that of threshold effect level (TEL) however, higher for $\mathrm{Hg}$ at the North Inlet. Nevertheless, it was still lower than potential effect level (PEL). Socio-economic interactions have dramatically reduced during the past two decades. Industrial sewage, river suspended sediments and agrochemicals such as fertilizers, pesticides were reportedly identified as the possible sources for heavy metal loads. Accumulation of toxic heavy metals can be minimized by detouring the water inflow to the lagoon.

\section{Introduction}

Wetlands, as natural habitats, are dispersed worldwide, providing niches for floral and faunal communities, ecological services and economic benefits for human welfare (UNESCO 1971; McCartney 2010). In a Sri Lankan context, Bambaradeniya (2004) has described twelve different categories of wetlands where lagoons are listed under 'saltwater wetlands'. Coastal lagoons, as highly productive ecosystems, provide numerous ecosystem goods and services and economic benefits including, provision of goods for human use, efficient nutrient cycling, absorption of storm energy and provision of flood protection and drainage, sediment trapping and water filtering, lagoon fisheries, ecotourism (Dahdouh-Guebas et al. 2021). However, the coastal lagoons have not escaped from human pressure.

In this respect, heavy metal (HM) pollution in aquatic environments has evidently become a menace due to their high toxicity, low solubility, wide range of sources, and bioaccumulation behavior of heavy metals (Yu et al. 2008). HM pollution has further been much concerned since it poses a high risk to aquatic organisms at different tropic levels due to biomagnification of xenobiotics through the food chain (Liu et al. 2018). In recent decades, a large amount of agricultural, industrial and domestic pollutants especially heavy metals, have been ended up in coastal aquatic ecosystems like lagoons, estuaries etc. (Wuana and Okieimen 2011; Kodikara 2021). Sediments at the bottom of the water body act as an indicator that is sensitive for monitoring of contaminants. They can also act as a sink and a transport agent for aquatic pollutants (Ulbrich et al. 1997). Therefore, determination of heavy metal contents in aquatic sediments is imperative to identify sources of heavy metal pollution (Diop et al. 2014). Further, spatial distribution of heavy metals in aquatic sediments can also provide valuable information regarding the impact of discharged waste on ecosystems and associated risk (Yan et al. 2010). This approach assists effective management of polluted aquatic ecosystems and also serves to monitor such systems (Li et al. 2016).

Whereas several studies in Sri Lanka have been carried out to assess the heavy metal content in food crops, land sediments, and atmospheric deposition (Herath et al. 2016; Subasinghe et al. 2016; Weerasundara et al. 2018) heavy metal contents in coastal aquatic ecosystems and spatial distribution of heavy metals received less attention. Adhikaram et al. (2016) reported the distribution and contamination status of environmentally important elements including major heavy metals of superficial sediments in the Batticaloa lagoon which is situated in the northern part of the eastern coast of Sri Lanka and it has been concluded that discharges from agricultural channel and marine fluxes of the lagoon effects on the spatial distribution of measured elements. Kalametiya Lagoon on the southern coast of Sri Lanka, on the other hand, has been subjected to an extensive discussion as the Udawalawe irrigation scheme that came into operation in 1967 has severely affected the lagoon over the past decades (Dahdouh-Guebas et al., 2005a), and continues to do so today (Madarasinghe et al. 2020a). In the Udawalawe project, drainage canals with excess water from paddy lands and other areas in the immediate neighborhood including industrial, urban and domestic areas, are connected to natural tributaries discharging in the sea through Kalametiya Lagoon downstream. This has caused heavy silt and pollutant input and salinity reduction. Further to that, Jayatissa et al. (2002b) and Dahdouh-Guebas et al. (2005a) have reported that socio-economic interactions with the lagoon have become nearly nil (i.e. drastic socioeconomic degradation) resulting from these hydrological alterations.

Taking these facts into account, this study set out to assess selected heavy metals/metalloids in surface sediments in Kalametiya Lagoon and their spatial distribution. The following research questions were addressed a) what is the average content of major heavy 
metals in Kalametiya Lagoon in 2020; b) what is the spatial distribution of HMs in the lagoon; c) Do the inhabitants around the lagoon still have interactions with Kalametiya lagoon.

\section{Methodology}

\section{Study site}

This study was conducted on the southern coast of Sri Lanka during the period of February-2019 and December-2020. The study site; Kalametiya Lagoon was selected for the study based on the fact that this coastal lagoon is highly affected by the aforementioned Udawalawe irrigation project. These intensive activities have caused deposition of loads of heavy metals in the lagoon resulting in changes in the lagoon biology and ecology. Therefore, this coastal ecosystem on the southern coast is considered as a model site to study HM pollution. Kalametiya Lagoon ( $6^{\circ} 04^{\prime} 26^{\prime \prime}-6^{0} 07^{\prime} 19^{\prime \prime} \mathrm{N}$ and $80^{\circ} 54^{\prime} 43^{\prime \prime}-80^{\circ} 57^{\prime} 25^{\prime \prime} \mathrm{E}$ ), located in the dry zone (annual rainfall is $<1750 \mathrm{~mm}$ ) about $65 \mathrm{~km}$ east from Matara (Fig. 1), is the largest lagoon on the southern coast of Sri Lanka, having an area of about $4.8 \mathrm{~km}^{2}$ at present. Several canals, streams and reservoirs feed Kalametiya Lagoon and Kuchchigal Ara, a seasonal river, is the main freshwater inflow to the lagoon. Most of the lagoon is muddy and covered with marsh vegetation. A narrow canal, reinforced by a rocky dyke, has been constructed under the Udawalawa irrigation scheme as a pathway for continuous outflow from the lagoon to the sea. After construction of this reinforced outlet, the natural mouth of the lagoon has been closed almost permanently by the formation of a sand bar. Meteorological data (2013-2018) obtained form Angunakolapelessa - the recording station nearest to Kalametiya Lagoon show that mean annual rainfall and monthly temperature for the area vary from 887-1476 mm (precipitation period: April-May and September-December) and from 29.7-33.0 ${ }^{\circ} \mathrm{C}$, respectively over the past decade (adapted from Madarasinghe et al. 2020a; Kodikara 2021). The present study was performed in five different areas ('sampling regions'), as shown in the map (Fig. 1), Lagoon Outlet (A), Centre (B \& F-M), Narrow West Stream (C \& N-P), Wide East Stream close to the inlet after paddy lands (D), North Inlet (E).

\section{Water and sediment sampling}

Both water and sediment samples were collected from the five major sampling areas (sampling points A-P) shown in the map. Water sampling was done at the sub water layers $(20-80 \mathrm{~cm}$ ) with the help of a Ruttner sampler (HYDRO-BIOS, PMMA Water Sampler, China). In total, 84 water samples were collected covering the major sampling areas (Lagoon Outlet: 12; Centre: 36; Narrow West Stream: 12; Wide East Stream: 12, North Inlet: 12). The samples were stored in cool conditions and pH and salinity were measured by using a pH meter (STRATER300, OHAUS, USA) and refractometer (ATAGOS/Mill-E, Japan) respectively. Sediment sampling was also carried out in the major sampling areas at a depth of $0-10 \mathrm{~cm}$ by using a bottom dredge sampler (Ponar grab, WILDCO, New York, USA). In total, 60 sediment samples (Lagoon Outlet: 10; Centre: 26; Narrow West Stream: 12; Wide East Stream: 06; North Inlet: 06) were collected and placed in labeled plastic bags and stored in cool conditions until analyses were performed.

\section{Acid digestion of sediment samples for heavy metal analysis}

The sediment samples were digested and the analyses for selected heavy metals i.e. Arsenic (As), Cadmium (Cd), Chromium (Cr), Lead $(\mathrm{Pb})$ and Mercury $(\mathrm{Hg})$ carried out following the methodology described by Wathsara et al. (2020) with minor modifications.

Approximately $0.5 \mathrm{~g}$ of finely powered dried sediment sample was weighed using the electronic balance (KERNTM KB2000-2N) into easy prep high-pressure microwave vessel, and approximately $10 \mathrm{~mL}$ of nitric acid was added and easy prep microwave digestion programme of the microwave digester (CEM MARS5, USA) was run to digest all samples. The digested samples were filtered with No.542 Whatman filter papers followed by washing with deionized water and volume up to $25 \mathrm{~mL}$ and metal ion content of samples were determined by Inductively Coupled Plasma Mass Spectrometer: ICP- MS (Agilent 700, USA).

\section{Questionnaire survey}

A questionnaire survey was conducted to obtain an overall view of the current socio-economic status of the lagoon and the possible effects of heavy metal pollution on socio-economy of the coastal dwellers. A standardized questionnaire (open-ended) was designed to evaluate the socio-economic status of Kalametiya Lagoon using a preliminary field survey and interviews. The key stakeholders were identified through a combination of methods: expert knowledge elicitation and preliminary field survey. The snowball sampling technique (Atkinson and Flint 2001) was used to identify further resource persons from whom more information could be collected. A face-to-face interview was carried out as a two-way interaction between respondent and interviewer (Kelley et al. 2003). In total, 45 people, including five community leaders, were interviewed individually in the survey. All men and women who have been living in the proximity of the 
lagoon, not less than 18 years were selected. Also, data from the questionnaire were cross-checked with secondary literature and field surveys to the best of our abilities.

\section{Data Analyses and kernel density mapping}

Heavy metal contents and physicochemical parameters were treated as continuous variables and descriptive statistics were studied along with data distribution patterns. Parametric assumptions such as normality of the data by the Shapiro-test, homogeneity of variances by the Levene's test were verified. As all the conditions were met for the dependent variables at 95\% confidence level, One-way ANOVA was performed to check the level of significance of heavy metal distribution among the sampling regions. Similarly, the level of significance was tested for physicochemical parameters among the sampling regions using One-way ANOVA. Pearson correlation test was performed to study correlation between physicochemical parameters of lagoon water and the heavy metal contents. All statistical analyses were performed using R-3.2.2 statistical software. Kernel density maps were prepared using the heavy metal contents obtained from 60 sediment samples representing the total spatiality of the lagoon. The maps were processed on ArcMap v. 10.6 .

\section{Results}

\section{Physicochemical parameters}

The results of the physicochemical parameters of water samples from five regions (A-E) in Kalametiya Lagoon are presented in Table1. The $\mathrm{pH}$ ranged between 6.58 - 6.92 with overall mean value of $6.68 \pm 0.17$. Water acidity varied with different regions of the lagoon and water collected near the North Inlet showed the highest acidity. The water samples collected from B (Centre), D (Wide East Stream), E (North Inlet) showed significantly higher $(\mathrm{p}<0.05)$ water acidity as compared to A (Outlet) and C (Narrow West Stream). Similarly, level of

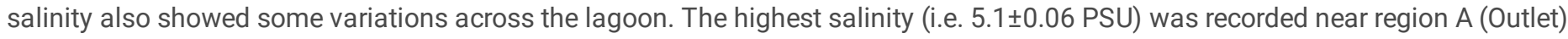
while the lowest (i.e. 1.1 \pm 0.25 PSU) was given for water near region $E$ (North Inlet). The overall mean salinity of the lagoon for the studied period was 2.9 \pm 2.2 PSU. Significantly higher salinity $(p<0.05)$ was recorded in region $A$ (Outlet) as compared to region $E$ (North Inlet). The level of salinity in regions B (Centre), D (Wide East Stream) and C (Narrow West Stream) was significantly higher ( $<<0.05)$ than region $E$ (North Inlet) while significantly lower than $(p<0.05)$ in region $A$ (Outlet).

\section{Spatial distribution of heavy metals}

The analytical results of the studied heavy metals are presented in Table 1 . When overall mean content was considered, heavy metal contents were in the descending order of $\mathrm{Cr}>\mathrm{Pb}>\mathrm{As}>\mathrm{Hg}>\mathrm{Cd}$ and the content ranges (mg/Kg) of the samples were $1.253-2.926 \mathrm{for} \mathrm{Cr}$, 0.137 - 0.411 for $\mathrm{Pb}, 0.137$ - 0.075 for As, 0.002-0.425 for Hg and $0.004-0.016$ for Cd. Further, according to the kernel maps (Fig. 2), the following descending order was observed: $\mathbf{A}$ (Outlet): $\mathrm{Cr}>\mathrm{Pb}>\mathrm{As}>\mathrm{Cd}>\mathrm{Hg}$; $\mathbf{B}$ (Centre): $\mathrm{Cr}>\mathrm{Pb}>\mathrm{AS}>\mathrm{Cd}>\mathrm{Hg}$; C (Narrow West $\mathrm{Stream}$ ): $\mathrm{Cr}>$ $\mathrm{Pb}>\mathrm{As}>\mathrm{Cd}>\mathrm{Hg}$; D (Wide East Stream): $\mathrm{Cr}>\mathrm{Pb}>\mathrm{As}>\mathrm{Cd}>\mathrm{Hg}$ and $\mathbf{E}$ (North Inlet): $\mathrm{Cr}>\mathrm{Hg}>\mathrm{Pb}>\mathrm{As}>\mathrm{Cd}$. The spatial distribution of the heavy metals was not monotonic and showed a highly spatial variation. The kernel density maps of the measured heavy metals demarcated several different areas of the lagoon since the sampling regions (A-E) have different compositions (Fig. 2). The distribution maps of Cr and $\mathrm{Pb}$ indicated significantly higher concentration $(\mathrm{p}<0.05)$ in $\mathrm{A}$ (Outlet), B (Centre), C (Narrow West Stream), E (North Inlet) regions as compared to D (Wide East Stream) region and As and Cd contents were significantly higher $(p<0.05)$ in $B(C e n t r e)$ region. In contrast, the distribution of $\mathrm{Hg}$ was comparatively greater in $\mathrm{E}$ (North Inlet) region.

The heavy metal content results further showed that the mean contents of $\mathrm{As}, \mathrm{Cd}, \mathrm{Cr}, \mathrm{Hg}$, and Pb were lower than that of threshold effect level (TEL) while it was higher for $\mathrm{Hg}$ at the $\mathrm{E}$ (North Inlet) region. However, it was still lower than potential effect level (PEL). Similarly, none of the studied heavy metal exceeded effect range low (ER-L) and effect range medium(ER-M). According to correlation results, Cr $(r=0.56)$ and $\mathrm{Pb}(\mathrm{r}=0.45)$ showed positive significant correlation with water $\mathrm{pH}$ while $\mathrm{Hg}(r=-0.53)$ had a negative significant correlation with salinity. The rest did not show any significant correlation with water $\mathrm{pH}$ and salinity.

\section{Socio-economic status of the lagoon}

There were $65 \%$ male and $35 \%$ female respondents. According to the questionnaire survey, $32 \%$ of the respondents engaged in lagoon fishery for their daily subsistence, $16 \%$ were farmers and the rest (52\%) involved in various occupations. Moreover, $53 \%$ of the farmers claimed that they had been using fertilizers such as Urea, Potash, Rock dust fertilizer, and general fertilizers for paddy lands (i.e., nitrogen $[\mathrm{N}]$, phosphorus [P], and potassium [K]). Moreover, $21 \%$ of interviewees stated that they had not used fertilizers and the rest (26\%) did not clearly answer the question. Dwellers in the area mentioned about the benefits that they have obtained from the lagoon during 2000 2019; $79 \%$ said that the local people largely engaged in fishing in the past, but now many of them are working in the bird sanctuary as 
tourist leaders in the lagoon. In addition, $90 \%$ of the respondents mentioned about the changes that had taken place during the past two decades; a) decrease of bird diversity and density; $b$ ) increase of mangroves and Typha (water sedge) plants; $c$ ) decrease of water salinity and lagoon depth; d) increase of freshwater fish species with shallow water column; e) bulky sedimentation has started with the onset of Udawalawe irrigation project; f) $75 \%$ of the respondents mentioned that lagoon water has become more toxic and hence was not no longer using used for drinking and bathing purposes. Furthermore, the respondents mentioned about the managerial actions that should have been taken to conserve Kalametiya Lagoon. The suggestions included a) removal of excess sedimentation; b) removal of aquatic invasive plants; $c$ ) widening of lagoon outlet; d) plantation of fibrous root plants along the main freshwater channel; e) strengthening institutional coordination; both government and non-governmental institutions.

\section{Discussion}

The Udawalawe irrigation project which came into operation in 1967 has caused to release of excess freshwater to Kalametiya Lagoon through Kuchchigal ara (Dahdouh-Guebas et al. 2005a; Madarasinghe et al. 2020a) resulting in desalination. In addition, due to the fact that the natural sand bar is not seasonally opened and the artificial dyke was constructed during the irrigation project, the ebb-flow system of the lagoon has been upset. Therefore, the tidal effect becomes minimal [Sri Lanka, anyway has a microtidal system (Kodikara et al., 2017a)]. This scenario has eventually caused reduction of the overall mean salinity level of the lagoon. In contrast, during the dry season, seawater intrusion becomes prominent and leads to increase in the lagoon salinity. Due to this fact, a spatial disparity in salinity distribution could be observed and it was no surprise for us to record the highest salinity at the lagoon outlet and the lowest at the inlet. It is evident that the lagoon ecology and biology are affected with such salinity reduction (Madarasinghe et al. 2020b) and salinity further plays a crucial role since increased salinity results in increasing metal bioavailability (Hou et al. 2013). In term of water pH, Ramanathan et al. (2005) recommended optimum range of $\mathrm{pH}$ 6.8-8.7 for proper function of a lagoon and the obtained mean value for water $\mathrm{pH}$ was lower than that of the prescribed range. This directly indicates a deterioration of water quality of Kalametiya Lagoon. In addition to $\mathrm{pH}$ and salinity, it is recommended to check dissolved oxygen, total suspended materials, redox potential, and organic matter content which may be useful in figuring out the holistic picture of the lagoon (Lawson 2011).

Heavy metals, as one of the top contaminants, have recently gained worldwide attention due to their high toxicity, environmental persistence, and accumulation in the environment and organism (Zhang et al. 2014). Heavy metal contents are mainly attributed to lithogenic and anthropogenic inputs (Kabata-Pendias and Mukherjee 2007). Two major causes are discussed for $\mathrm{Cr}$ enrichment in the lagoon. It is apparent that sediments are brought to the lagoon with excess freshwater and that bulky sedimentation may have caused to add more $\mathrm{Cr}$ to the lagoon. There is evidence which reflects that lithogenic components; i.e. produced from the weathering of bedrocks and soils (Yunginger et al. 2018) in upper areas are transported by water which then settled at the bottom of downstream water bodies (Tamuntuan et al. 2015). The other probable source of $\mathrm{Cr}$ may be phosphate fertilizers, used in agricultural fields in the area (Dissanayaka and Chandrajith 2009). There is a high likelihood to get solubilized phosphate fertilizers when excess freshwater flows through the agricultural lands, situated at the upstream areas. In addition, Dissanayaka and Chandrajith (2009) reported that the phosphate fertilizers used in Sri Lanka contain not only $\mathrm{Cr}$, but also high amounts of heavy metals including $\mathrm{Ni}$, and $\mathrm{Pb}$. Furthermore, $\mathrm{Zn}$, $\mathrm{Cu}, \mathrm{Cd}, \mathrm{Pb}$, and As have also been identified as widely used heavy metals in agricultural fertilizers, pesticides and fungicides (GimenoGarci'a et al. 1996; Kelepeitzis 2014). Therefore, As, Cd and Pb could be linked with agricultural fertilizers, being used in the area. Although Adikaram et al. (2016) reported that most marine algae produce organoarsenic compounds, for example in Batticaloa lagoon, it is unlikely to be applicable in Kalametiya Lagoon since material exchange is minimal at the lagoon outlet. When $\mathrm{Hg}$ is considered, that could be due to higher input from the domestic sewage and hospital effluents (Wang et al. 2017). Moreover, metal processing, stainless steel welding, chromate production, tannery facilities and ferrochrome and chrome pigment production could largely contribute to heavy metal release as well (ATSDR 2012). It is well-known that water pH directly influences the heavy metal concentrations by altering bioavailability and toxicity. Metals such as $\mathrm{Cd}, \mathrm{Pb}$ and $\mathrm{Hg}$ are most likely to have significant correlation with water $\mathrm{pH}$ and are recorded to increase detrimental environmental effects with increasing acidity (DWAF 1996). It has been found that water pH governs the methylation of elements such as $\mathrm{Pb}$ and $\mathrm{Hg}$ (van Loon 1982) that was best reflected by significant correlation shown for Hg in this study.

It is commonly observed that, except $\mathrm{Hg}$, the rest are largely accumulated at the Centre and Outlet of the lagoon. Higher accumulation of heavy metals at these regions is due to poor ebb-flow system of the lagoon which happened due to the artificial dyke construction and natural sand barrier. In general, mosaic distribution of heavy metals in Kalametiya Lagoon could be due to the limited circulation taking place inside the lagoon. Furthermore, the increasing trend of heavy metals in the lagoon from the Inlet (E) to the Outlet (A) might be due to the process of sediment accumulation pattern from upstream to downstream of the lagoon (Dahdouh-Guebas et al. 2005b). Though the sediment undergoes resuspension, redox reaction and biodegradation, considerably changing the affinity of the sediment, it is 
considered to be the depositing compartment of the marine environment. The distribution and accumulation of heavy metal depend on grain size. Therefore, more insight would be gained if grain size analysis would have been done (EINemr et al. 2007).

When current pollution status is taken into consideration, Kalametiya Lagoon is not at stake as the heavy metal contents did not exceed TEL and PEL. In Sri Lanka, few studies have focused on heavy metal pollution in several water bodies and lagoons including Kumbichchankulama, Alankulama, Thuruwila, dry zone and Negombo Lagoon (Bandara et al. 2008; Chandrajith et al. 2012; Sivanantha et al. 2016). According to their results, Negombo Lagoon showed the highest content of heavy metals in the published data of Sri Lanka, for example, As: $9.89 \mathrm{mg} / \mathrm{Kg}$; Cd: $2.63 \mathrm{mg} / \mathrm{Kg}$; Cr: $26.1 \mathrm{mg} / \mathrm{Kg}$; Pb: $20.26 \mathrm{mg} / \mathrm{Kg}$. In rest of the water bodies also, Cd content was greater than $2.18 \mathrm{mg} / \mathrm{Kg}$. Therefore, the pollution level of Kalametiya Lagoon is far below the aforementioned figures in the other water bodies. Since this excess freshwater flow continues, higher levels of pollution can be expected soon. On the other hand, survey data clearly reflect that socio-economic interactions have become minimal and less than $5 \%$ of the dwellers now depend on lagoon fisheries. Further, the dwellers have indirectly experienced water quality changes including toxicity (sudden fish death, skin irritation). Due to this fact, majority of the dwellers are reluctant in using lagoon water for their daily use. However, such kind of livelihood transformations are not uncommon in Sri Lanka as well as the other parts of the world (Okello et al. 2019; Madarasinghe et al. 2020a, 2020b).

To minimize the impact of heavy metal pollution at this stage, it is recommended to implement eco-sustainable remedies like construction of a separate canal to dispose excess water coming from the Udawalawe irrigation project, introduction of a cascade system to freshwater canals before entering to the lagoon which would minimize sediment loading, periodic removal of accumulated sediments manually, and use of phytoremediation techniques.

\section{Concluding Remarks}

Kalametiya Lagoon in southern Sri Lanka is polluted with heavy metals like $\mathrm{As}, \mathrm{Cd}, \mathrm{Cr}, \mathrm{Hg}$ and $\mathrm{Pb}$. heavy metal contents were in the descending order of $\mathrm{Cr}>\mathrm{Pb}>\mathrm{As}>\mathrm{Hg}>\mathrm{Cd}$. The spatial distribution of the heavy metals was not monotonic and showed a highly spatial variation. According to the kernel maps, the following descending order could be observed: $\mathrm{A}$ (Outlet): $\mathrm{Cr}>\mathrm{Pb}>\mathrm{As}>\mathrm{Cd}>\mathrm{Hg} ; \mathrm{B}$ (Centre): $\mathrm{Cr}>\mathrm{Pb}>\mathrm{AS}>\mathrm{Cd}>\mathrm{Hg} ; \mathrm{C}$ (Narrow West Stream): $\mathrm{Cr}>\mathrm{Pb}>\mathrm{As}>\mathrm{Cd}>\mathrm{Hg}$; D (Wide East Stream): $\mathrm{Cr}>\mathrm{Pb}>\mathrm{As}>\mathrm{Cd}>\mathrm{Hg}$ and $\mathrm{E}$ (North Inlet): $\mathrm{Cr}$

$>\mathrm{Hg}>\mathrm{Pb}>\mathrm{As}>\mathrm{Cd}$. The mean contents of $\mathrm{As}, \mathrm{Cd}, \mathrm{Cr}, \mathrm{Hg}$, and $\mathrm{Pb}$ were lower than that of Threshold Effect Level (TEL) and Potential Effect Level (PEL). Similarly, none of the studied heavy metals/metalloids exceeded Effect Range Low (ER-L) and Effect Range Medium(ER-M). Therefore, Kalametiya Lagoon is not at stake at this point. However, if this trend continues, higher levels of pollution can be expected soon. On the other hand, survey data clearly reflect that socio-economic interactions have become minimal and less than $5 \%$ of the dwellers now depend on lagoon fisheries.

\section{Declarations}

\section{Conflicts of interest/Competing interests}

The authors have no conflicts of interest to declare.

\section{Availability of data and material}

Data are given in table format

\section{Code availability}

Not applicable

\section{Authors' contributions}

KKAS \& HT: Designed the research and carried out field sampling; PMCS, RP, HPPS, DM and FDG: Supervised the research; MSK \& GDUV: Did laboratory experiments; LPJ, AJ, FDG and KKAS: Wrote the paper and given financial assistance.

\section{Ethics approval}

Not applicable

\section{Consent to participate}


Not applicable

\section{Consent for publication}

Not applicable

\section{References}

1. Adikaram M, Pitawala A, Ishiga H, Jayawardana D (2016) Spatial distribution, enrichment, and source of environmentally important elements in Batticaloa lagoon, Sri Lanka. Environ Sci Pollut Res 24:2089-2099. https://doi.org/10.1007/s11356-016-7973-6

2. Atkinson R, Flint J (2001) Accessing hidden and hard-to-reach populations: Snowball research strategies. Social research update 33(1):1-4

3. ATSDR (2012) Toxicological Profile for Chromium. Agency for Toxic Substances and Disease Registry. U.S, Department of Health

4. Bambaradeniya CNB (2004) Freshwater Wetlands in Sri Lanka: Their Conservation Significance and Current Status. Proceedings of the National Symposium on Wetland Conservation and Management 19-24

5. Bandara JMRS, Senevirathna DMAN, Dasanayake DMRSB, Herath V, Bandara JMRP, Abeysekara T, Rajapaksha KH (2008) Chronic renal failure among farm families in cascade irrigation systems in Sri Lanka associated with elevated dietary cadmium levels in rice and freshwater fish (Tilapia). Environ Geochem Health 30(5):465-478. https://doi.org/10.1007/s10653-007-9129-6

6. Chandrajith R, Ariyaratna T, Dissanayake C (2012) The status of cadmium in the geo-environment of Sri Lanka. Ceylon Journal of Science (Physical Sciences) 16:47-53

7. Dahdouh-Guebas F, Jayatissa LP, Di Nitto D, Bosire JO, Lo Seen D, Koedam N (2005a) How Effective Were Mangoves as a Defence against the Recent Tsunami? Curr Biol 15(12):R443-R447. https://doi.org/10.1016/j.cub.2005.06.008

8. Dahdouh-Guebas F, Hug'e J, Abuchahla GMO, Cannicci S, Jayatissa LP, Kairo JG, Kodikara Arachchilage Sunanda, Koedam N, Mafaziya Nijamdeen TWGF, Mukherjee N, Poti M, Prabakaran N, Ratsimbazafy HA, Satyanarayana B, Thavanayagam M, Vande Velde K, Wodehouse D (2021) Reconciling nature, people and policy in the mangrove socialecological system through the adaptive cycle heuristic. Estuarine, Coastal and Shelf Science 248:106942

9. Department of Water Affairs and Forestry (DWAF) (1996) South African Water Quality Guidelines, Domestic Use, vol 1, 2nd edn. DWAF, Pretoria

10. Diop C, Dewaele D, Diop M, Toure A, Cabral M, Cazier F, Fall M, Diouf A, Ouddane B (2014) Assessment of contamination, distribution and chemical speciation of trace metals in water column in the Dakar coast and the Saint Louis estuary from Senegal, West Africa. Mar Pollut Bull 86(1-2):539-546. https://doi.org/10.1016/j.marpolbul.2014.06.051

11. Dissanayaka CB, Chandrajith R (2009) Phosphate mineral fertilizers, trace metals and human health. J Nat Sci Found Sri Lanka 37(3):153-165. https://doi.org/10.4038/jnsfsr.v37i3.1219

12. ElNemr AH, El Sikaily A, Khaled A (2007) Total and leachable heavy metals in muddy and sandy sediments of Egyptian coast along Mediterranean Sea. J Coast Shelf Sci 129:151-168. https://doi.org/10.1007/s10661-006-9349-8

13. Gimeno-Garci'a E, Andreu V, Boluda R (1996) Heavy metals incidence in the application of inorganic fertilizers and pesticides to rice farming soils. Environ Pollut 92:19-25. https://doi.org/10.1016/0269-7491(95)00090-9

14. Herath D, Pitawala A, Gunatilake J (2016) Heavy metals in road deposited sediments and road dusts of Colombo Capital, Sri Lanka. J Nat Sci Found Sri Lanka 44(2):193-202. http://doi.org/10.4038/jnsfsr.v44i2.8000

15. Hou D, He J, Lu“ C, Ren L, Fan Q, Wang J, Xie Z (2013) Distribution characteristics and potential ecological risk assessment of heavy metals ( $\mathrm{Cu}, \mathrm{Pb}, \mathrm{Zn}, \mathrm{Cd})$ in water and sediments from Lake Dalinouer, China. Ecotoxicol Environ Saf 93:135-144. https://doi.org/10.1016/j.ecoenv.2013.03.012

16. Jayatissa LP, Guero MC, Hettiarachchi S, Koedam N (2002) Changes in vegetation cover and socio-economic transitions in a coastal lagoon (Kalametiya, Sri Lanka), as observed by teledetection and ground truthing, can be attributed to an upstream irrigation scheme. Environ Dev Sustain 4(2):167-183. https://doi.org/10.1023/A:1020831416827

17. Kabata-Pendias A, Mukherjee AB (2007) Trace Elements from Soil to Human. Springer, Berlin

18. Kelepertzis E (2014) Accumulation of heavy metals in agricultural soils of Mediterranean: insights from Argolida basin, Peloponnese, Greece. Geoderma 221-222:82-90. https://doi.org/10.1016/j.geoderma.2014.01.007

19. Kelley K, Clark B, Brown V, Sitzia J (2003) Good practice in the conduct and reporting of survey research. International Journal for Quality in health care 15(3):261-266. https://doi.org/10.1093/intqhc/mzg031

Page $7 / 11$ 
20. Kodikara KAS (2021) Phytoremediation capacity of aquatic floating plants; Salvinia molesta and Eichhornia crassipes in desalinated Kalametiya Lagoon, southern coast of Sri Lanka. WILDLANKA 9(1):150-159

21. Lawson EO (2011) Physico-Chemical Parameters and Heavy Metal Contents of Water from the Mangrove Swamps of Lagos Lagoon, Lagos, Nigeria. Advances in Biological Research 5(1):08-21

22. Li R, Chai M, Qiu GY (2016) Distribution, fraction, and ecological assessment of heavy metals in sediment-plant system in Mangrove Forest, South China Sea. PLoS One 11(1):e0147308. https://doi.org/10.1371/journal.pone.0147308

23. Liu Y, Liu G, Yuan Z, Liu H, Lam PK (2018) Heavy metals (As, Hg and V) and stable isotope ratios (d13C and d15N) in fish from Yellow River Estuary, China. Sci Total Environ 613:462-471. https://doi.org/10.1016/j.scitotenv.2017.09.088

24. Madarasinghe SK, Yapa KKAS, Satyanarayana B, Udayakantha PMP, Kodikara S, Jayatissa LP (2020) Inland Irrigation Project Causes Disappearance of Coastal Lagoon: The Trajectory of Kalametiya Lagoon, Sri Lanka from 1956 to 2016. Coastal Management 48(3):188-209. https://doi.org/10.1080/08920753.2020.1747914

25. Madarasinghe SK, Yattowita Withanage Praveen Amarasinghe YWP, Liyanage CH, Gunathilake HMSAT, Jayasingha JAIK, Jayasingha M, Priyankara WKL, Kodikara KAS, Koedam N, Dahdouh-Guebas F, Jayatissa LP (2020) Retrospective study on changes in Dondra lagoon (2006-2017) resulting from tsunami impact and post-tsunami development. Journal of Coastal Conservation 24(5):1-11. https://doi.org/10.1007/s11852-020-00777-1

26. McCartney M, Rebelo LM, Senaratna Sellamuttu S, De Silva S (2010) Wetlands, agriculture and poverty reduction. International Water Management Institute (IWMI), Colombo, Sri Lanka. IWMI Research Report 137:39. https://doi.org/10.5337/2010.230

27. Okello JA, Alati V, Kodikara S, Kairo JG, Dahdouh-Guebas F, Koedam N (2019) The status of Mtwapa Creek mangroves as perceived by the local communities. WIO Journal of Marine Science 18(1):67-81. https://doi.org/10.4314/wiojms.v18i1.7

28. Ramanathan NP, Padmavathy T, Francis S, Athithian, Selvaranjitham N (2005) Manual on polyculture of tiger shrimp and carps in freshwater, 1. Tamil Nadu Veterinary and Animal Sciences University, Fisheries College and Research Institute, Thothukudi, p 161

29. Sivanantha N, Wijesinghe MR, Wijesekara RD (2016) Distribution of five toxic heavy metals in biotic and abiotic constituents of the Negombo Lagoon, Sri Lanka. Sri Lankan Journal of Biology 1(1):1-14. http://doi.org/10.4038/sljb.v1i1.1

30. Subasinghe S, Estoque RC, Murayama Y (2016) Spatiotemporal analysis of urban growth using GIS and remote sensing: A case study of the Colombo Metropolitan Area, Sri Lanka. Int J Geo-Inf 5:197. https://doi.org/10.3390/ijgi5110197

31. Tamuntuan G, Bijaksana S, King J, Russell J, Fauzi U, Maryunani K, Aufa N, Safiuddin LO (2015) Variation of magnetic properties in sediments from Lake Towuti, Indonesia, and its paleoclimate significance. Palaeogeogr Palaeoclimatol Palaeoecol 420:163-172. https://doi.org/10.1016/j.palaeo.2014.12.008

32. Ulbrich K, Marsula R, Jeltsch F, Hofmann H, Wissel C (1997) Modelling the ecological impact of contaminated river sediments on wetlands. Ecological modelling 94(2-3):221-230. https://doi.org/10.1016/S0304-3800(96)00023-3

33. UNESCO (United Nations Educational, Scientific and Cultural Organization) (1971) Convention on Wetlands of International Importance especially as Waterfowl Habitat, Ramsar Iran-1971. The List of Wetlands of International Importance. Available at RamsarWeb. https://www.ramsar.org/sites/default/files/documents/library/sitelist.pdf. Accessed 1 September 2021

34. Van Loon JC (1982) Chemical Analysis of Inorganic Constituent of Water. CRC Press

35. Wang L, Ji B, Hu Y, Liu R, Sun W (2017) A review on in situ phytoremediation of mine tailings. Chemosphere 184:594-600. https://doi.org/10.1016/j.chemosphere.2017.06.025

36. Wathsara HPT, Weeratunge HD, Mubarak MNA, Godakumbura PI, Ranasinghe P (2020) In Vitro Antioxidant and Antidiabetic Potentials of Syzygium caryophyllatum L. Alston. Evidence-Based Complementary Alternative Medicine 2020:1-15. https://doi.org/10.1155/2020/9529042

37. Weerasundara L, Magana-Arachchi DN, Ziyath AM, Goonetilleke A, Vithanage M (2018) Health risk assessment of heavy metals in atmospheric deposition in a congested city environment in a developing country: Kandy City, Sri Lanka. J Environ Manag 220:198206. https://doi.org/10.1016/j.jenvman.2018.04.036

38. Wuana RA, Okieimen FE (2011) Heavy metals in contaminated soils: a review of sources, chemistry, risks and best available strategies for remediation. ISRN Ecology 1-20. https://doi.org/10.5402/2011/402647

39. Yan C, Li Q, Zhang X, Li G (2010) Mobility and ecological risk assessment of heavy metals in surface sediments of Xiamen Bay and its adjacent areas, China. Environ Earth Sci 60(7):1469-1479. https://doi.org/10.1007/s12665-009-0282-3

40. Yu RL, Yuan X, Zhao YH, Hu GR, Tu XL (2008) Heavy metal pollution in intertidal sediments from Quanzhou Bay, China. J Environ Sci 20:664-669. https://doi.org/10.1016/S1001-0742(08)62110-5

Page 8/11 
41. Yunginger R, Bijaksana S, Dahrin D, Zulaikah S, Hafidz A, Kirana KH, Sudarningsih, Mariyanto, Fajar SJ (2018) Lithogenic and Anthropogenic Components in Surface Sediments from Lake Limboto as Shown by Magnetic Mineral Characteristics, Trace Metals, and REE Geochemistry. Geosciences 8(4):116. https://doi.org/10.3390/geosciences8040116

42. Zhang C, Yu ZG, Zeng GM, Jiang M, Yang ZZ, Cui F, Zhu MY, Shen LQ, Hu L (2014) Effects of sediment geochemical properties on heavy metal bioavailability. Environ Int 73:270-281. https://doi.org/10.1016/j.envint.2014.08.010

\section{Tables}

Table 1 Descriptive details of heavy metals contents $(\mathrm{mg} / \mathrm{kg})$ in the surface sediments of the study area. Mean \pm SD of heavy metals are reported for the results obtained from the present study.

\begin{tabular}{|c|c|c|c|c|c|c|c|c|}
\hline Sites & As (mg/Kg) & $\mathrm{Cd}(\mathrm{mg} / \mathrm{Kg})$ & $\mathrm{Cr}(\mathrm{mg} / \mathrm{Kg})$ & $\mathrm{Hg}(\mathrm{mg} / \mathrm{Kg})$ & $\mathrm{Pb}(\mathrm{mg} / \mathrm{Kg})$ & Reference & $\mathrm{pH}$ & $\begin{array}{l}\text { Salinity } \\
\text { (PSU) }\end{array}$ \\
\hline Outlet (A) & $0.104 \pm 0.003$ & $0.007 \pm 0.001$ & $2.635 \pm 0.617$ & $0.002 \pm 0.001$ & $\begin{array}{l}0.347 \pm \\
0.076\end{array}$ & $\begin{array}{l}\text { Present } \\
\text { study }\end{array}$ & $6.85 \pm 0.07$ & $5.1 \pm 0.06$ \\
\hline Centre (B) & $0.137 \pm 0.012$ & $0.014 \pm 0.005$ & $2.723 \pm 0.723$ & $0.004 \pm 0.002$ & $0.411 \pm 0.191$ & $\begin{array}{l}\text { Present } \\
\text { study }\end{array}$ & $6.61 \pm 0.03$ & $2.4 \pm 0.04$ \\
\hline $\begin{array}{l}\text { Narrow } \\
\text { West } \\
\text { Stream (C) }\end{array}$ & $0.112 \pm 0.018$ & $0.016 \pm 0.002$ & $2.926 \pm 1.081$ & $0.002 \pm 0.001$ & $0.315 \pm 0.071$ & $\begin{array}{l}\text { Present } \\
\text { study }\end{array}$ & $6.73 \pm 0.02$ & $2.7 \pm 0.05$ \\
\hline $\begin{array}{l}\text { Wide East } \\
\text { Stream (D) }\end{array}$ & $0.082 \pm 0.022$ & $0.004 \pm 0.003$ & $1.253 \pm 0.437$ & $0.003 \pm 0.001$ & $0.137 \pm 0.045$ & $\begin{array}{l}\text { Present } \\
\text { study }\end{array}$ & $6.60 \pm 0.05$ & $3.1 \pm 0.04$ \\
\hline $\begin{array}{l}\text { North Inlet } \\
\text { (E) }\end{array}$ & $0.075 \pm 0.036$ & $0.004 \pm 0.003$ & $1.849 \pm 1.323$ & $0.425 \pm 0.134$ & $0.235 \pm 0.160$ & $\begin{array}{l}\text { Present } \\
\text { study }\end{array}$ & $6.62 \pm 0.04$ & $1.1 \pm 0.25$ \\
\hline $\begin{array}{l}\text { Threshold } \\
\text { effect level } \\
\text { (TEL) }{ }^{i}\end{array}$ & 7.420 & 0.680 & 52.30 & 0.130 & 30.200 & $\begin{array}{l}\text { Macdonald } \\
\text { et al. } \\
(2000)\end{array}$ & & \\
\hline $\begin{array}{l}\text { Probable } \\
\text { effect level } \\
\text { (PEL) }{ }^{i}\end{array}$ & 41.600 & 4.200 & 160.400 & 0.700 & 112.200 & $\begin{array}{l}\text { Macdonald } \\
\text { et al. } \\
(2000)\end{array}$ & & \\
\hline $\begin{array}{l}\text { Effect range } \\
\text { low (ER-L) ii }\end{array}$ & 8.200 & 1.200 & 81.000 & 0.150 & 46.700 & $\begin{array}{l}\text { Long et al. } \\
\text { (1995) }\end{array}$ & & \\
\hline $\begin{array}{l}\text { Effect range } \\
\text { medium(ER- } \\
\text { M) ii }\end{array}$ & 70.000 & 9.600 & 370.000 & 0.170 & 218.000 & $\begin{array}{l}\text { Long et al. } \\
(1995)\end{array}$ & & \\
\hline
\end{tabular}

* SD: Standard deviation; TEL: Threshold Effect Level, represents the concentration below which adverse biological effects are rarely expected to occur; PEL: Probable Effect Level (PEL), defines the level above which adverse effects are expected to occur frequently; ER-L: Effect Range-Low, is interpreted with a rare biological effect. ER-M: Effect Range-Medium, indicates frequent biological effects. i) Threshold effect level or probable effect level for marine and estuarine sediments (Long et al. 1995). ii) Sediment quality guidelines for metals in the freshwater ecosystem (Macdonald et al. 2000)

\section{Figures}




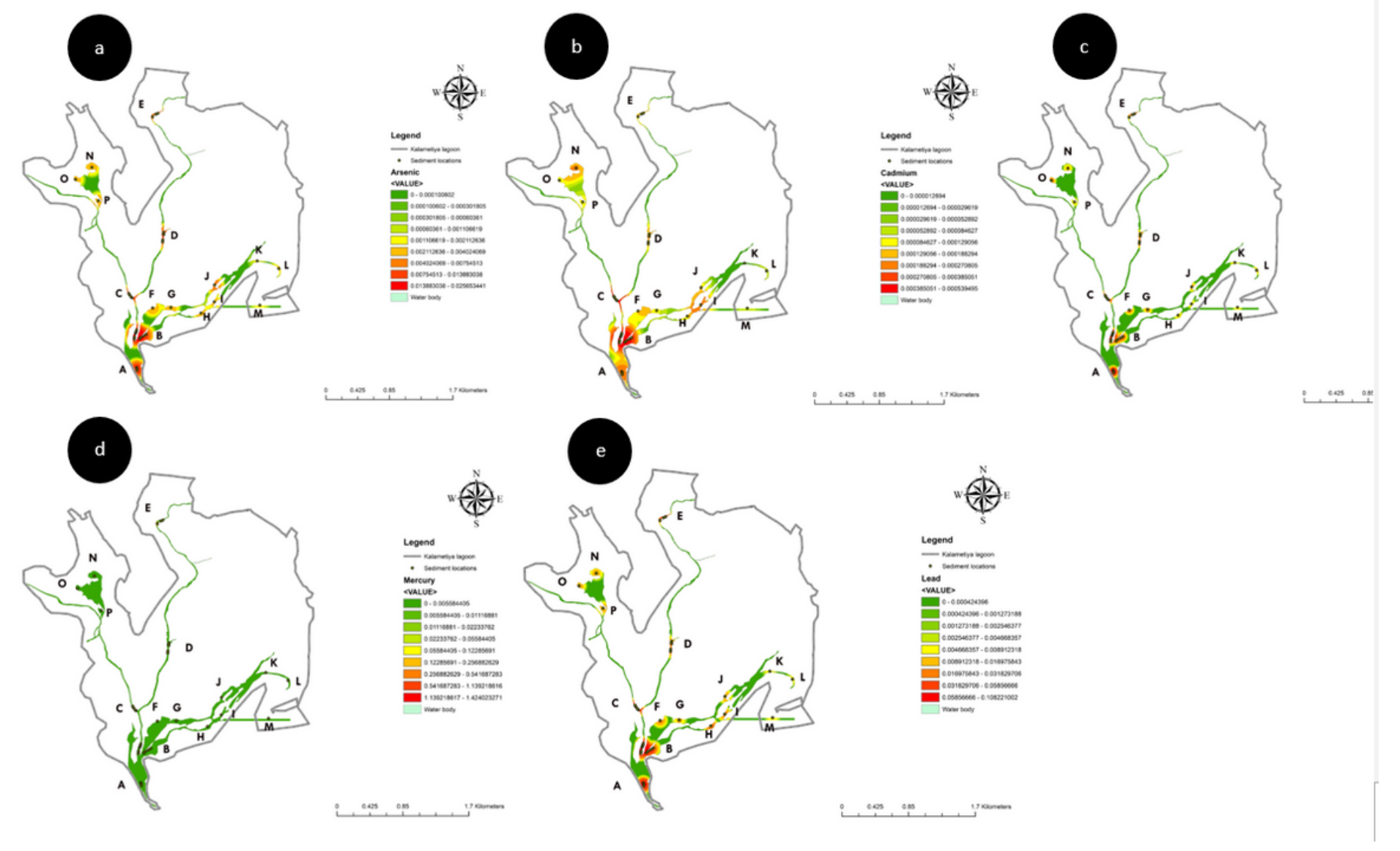

Figure 1

Map of Sri Lanka (left side) and location of Kalametiya Lagoon (right side) on the southern coast of Sri Lanka, approximately $65 \mathrm{~km}$ to the east of Matara, in the dry zone

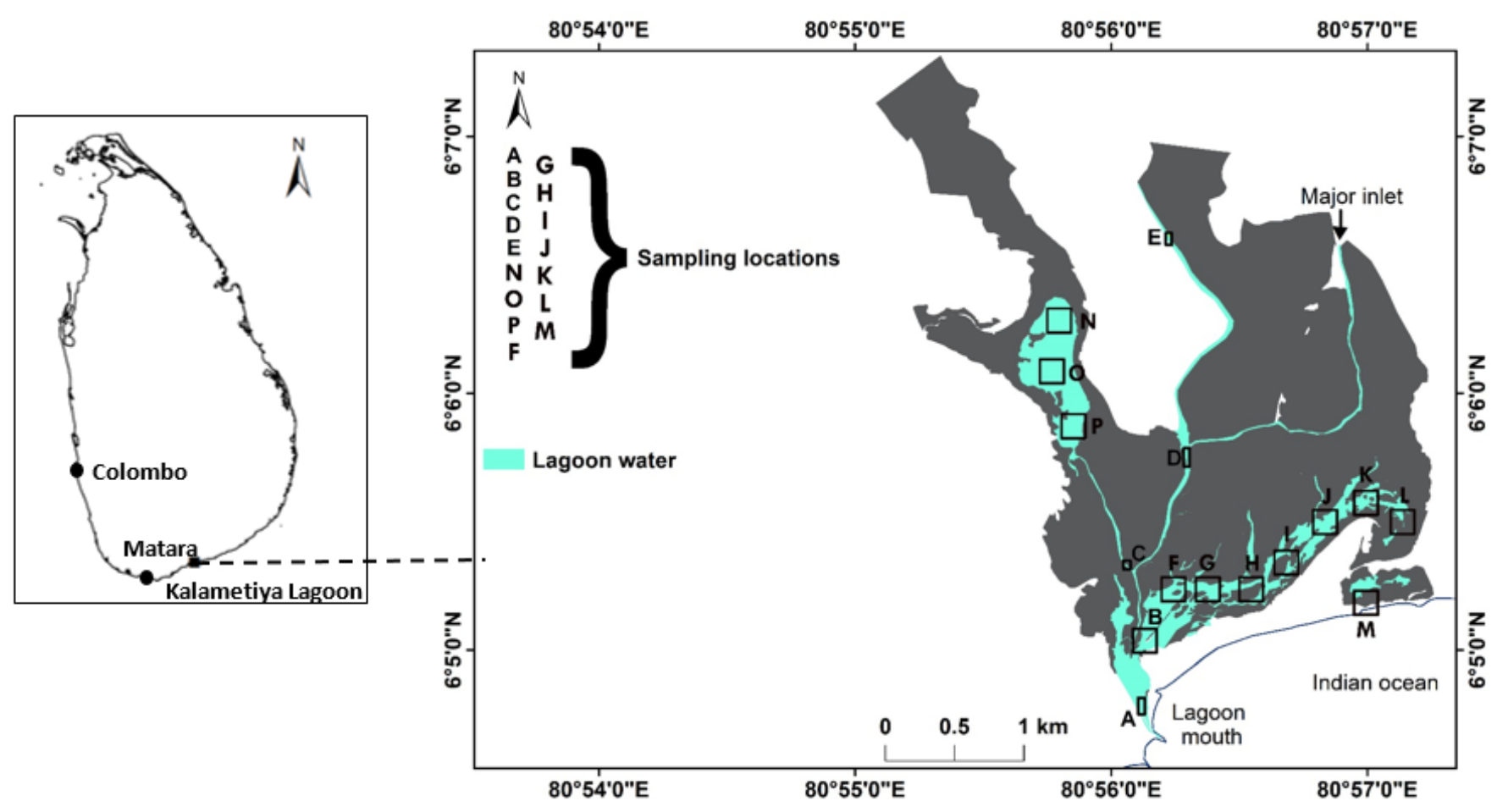

Figure 2 
Kernel density maps (a-e) reflect spatial distribution of the studied heavy metals; a: As; b: Cd; c: Cr; d: Hg; e: Pb. Ranges of heavy metal contents are given in map legends. Major sampling regions of the lagoon are A: Outlet; B: Centre; C: Narrow West Stream; D: Wide East Stream; E: North Inlet. 